\title{
A STEP BY STEP DESIGN GUIDE FOR A SOLAR WATER HEATING SYSTEM CONSIDERING THERMAL LOSSES
}

\begin{abstract}
R. R. Barbosa ${ }^{a}$, and M. Carvalho ${ }^{b}$

${ }^{a}$ Universidade Federal da Paraíba Programa de Pós-Graduação em Engenharia

Mecânica

Centro de Tecnologia rafaela.barbosa@cear.ufpb.br

bUniversidade Federal da Paraíba Departamento de Engenharia de Energias Renováveis Centro de Energias Alternativas e Renováveis

\section{ABSTRACT}

A clear and direct guide for the design of a solar heating system is presented herein, focused on industrial applications. This guide focuses on the design of solar water heating systems for nonresidential applications. The importance of considering climatic conditions throughout the year is highlighted herein, along with reliable solar radiation data. Solar heating water systems are essential for the diversification of the Brazilian energy matrix and rationalization of the energy resources available. The system is initially dimensioned without the consideration of losses. Then, the required procedure to calculate thermal losses is described, and it is verified that the main losses occur in solar collectors and storage. After careful consideration of the hot water consumption profile and the results obtained in the calculation of the main thermal losses, the storage volume was doubled to guarantee the satisfaction of energy demands.
\end{abstract} Cidade Universitária - João Pessoa - PB - Brasil CEP: 58051-970, Caixa Postal 5115 monica@cear.ufpb.br Received: April 22, 2019 Revised: May 17, 2019 Accepted: June 10, 2019
Keywords: design; water heating; solar energy; industry

\section{NOMENCLATURE}

$\mathrm{A}_{\mathrm{c}} \quad$ area of the solar collector set, $\mathrm{m}^{2}$

$\mathrm{A}_{\mathrm{col}}$ area of the solar collector unit, $\mathrm{m}^{2}$

$\mathrm{A}_{\text {sides }}$ area of sides of the solar collector, $\mathrm{m}^{2}$

$\mathrm{A}_{\mathrm{TA}}$ area of the storage tank, $\mathrm{m}^{2}$

$\mathrm{A}_{\mathrm{tc}}$ area of the glass cover of the solar collector, $\mathrm{m}^{2}$

b width of the surface-tube junction, $m$

$\mathrm{C}_{\mathrm{p}} \quad$ fluid specific heat at constant $\mathrm{f}$ water, $\mathrm{J} /(\mathrm{kg} . \mathrm{K})$

$\mathrm{D}_{\mathrm{e}} \quad$ outer diameter of the tubes of the solar collector, $\mathrm{m}$

$\mathrm{D}_{\mathrm{i}} \quad$ inner diameter of the tubes the of the solar collector, $\mathrm{m}$

$\mathrm{E}_{\text {useful }}$ daily demand of useful energy, kWh/day

$\mathrm{f} \quad$ solar fraction of the system

$\mathrm{f}_{\mathrm{a}} \quad$ friction factor of the flow inside the tubes

F collector fin efficiency factor for straight fins

$\mathrm{F}$, heat collection efficiency factor

$\mathrm{F}_{\mathrm{R}}$ heat removal factor

$h_{\text {ca }}$ convective coefficient between the glass cover of the collector and the air, $\mathrm{W} /\left(\mathrm{m}^{2} . \mathrm{K}\right)$

$\mathrm{h}_{\mathrm{t}}$ convection coefficient within the tubes, $\mathrm{W} /\left(\mathrm{m}^{2} . \mathrm{K}\right)$

I incident energy on the collector area, $\mathrm{MJ} / \mathrm{m}^{2}$

$\mathrm{k}$ thermal conductivity of the absorber surface, $\mathrm{W} /(\mathrm{m} . \mathrm{K})$

$\mathrm{k}_{\mathrm{i}} \quad$ thermal conductivity of the thermal insulation, $\mathrm{W} /(\mathrm{m} . \mathrm{K})$

$\mathrm{k}_{\mathrm{b}}$

thermal conductivity of the surface-tube junction, $\mathrm{W} /(\mathrm{m} . \mathrm{K})$

$l_{i} \quad$ thickness of the thermal insulation, $m$

$\mathrm{m}_{\text {cons }} \quad$ daily water consumption, $\mathrm{kg}$

$\mathrm{m}_{\mathrm{c}} \quad$ mass flow in a collector, $\mathrm{kg}$

$\mathrm{m}_{\text {consumption }}$ daily water consumption, $\mathrm{kg}$

$\mathrm{m}_{\text {storage }} \quad$ mass of the stored liquid, $\mathrm{kg}$

$n$ thermal efficiency of the solar collector

$\mathrm{N}$ number of glass covers in the collector

$\mathrm{N}_{\text {collectors }}$ number of solar collectors required

$\mathrm{N}_{\mathrm{t}} \quad$ number of tubes in the collector

$\mathrm{Nu} \quad$ Nusselt number

Pr fluid Prandtl number, $v / \alpha$

$\mathrm{P}_{\mathrm{a}} \quad$ precision limit of quantity a

$\mathrm{Q}_{\mathrm{u}} \quad$ energy absorbed per hour in the collector area, J

$\mathrm{Q}_{\mathrm{P}} \quad$ energy losses in the collectors, J

$Q_{\text {tot }} \quad$ energy gains in the collectors, $J$

$\mathrm{Q}_{\text {storage }} \quad$ internal energy storage capacity, J.

Re Reynolds number

S solar irradiance, $\mathrm{W} / \mathrm{m}^{2}$

$\mathrm{t}$ thickness of the absorber surface, $\mathrm{m}$

$\mathrm{T}_{\mathrm{abs}} \quad$ temperature of the absorber surface, $\mathrm{K}$

$\mathrm{T}_{\mathrm{amb}} \quad$ average annual ambient temperature at the site, $\mathrm{K}$

$\mathrm{T}_{\mathrm{C} 1}, \mathrm{~T}_{\mathrm{C} 2} \quad$ water temperature at the inlet and outlet of the solar collectors, $\mathrm{K}$

$\mathrm{T}_{\text {consumption }} \quad$ temperature of water consumed, $\mathrm{K}$

$\mathrm{T}_{\text {process }}$ temperature the of required process, $\mathrm{K}$

$\mathrm{T}_{\text {storage }} \quad$ water storage temperature, $\mathrm{K}$

$\mathrm{T}_{\mathrm{mf}} \quad$ average temperature of the water in the 
collectors. K

$\mathrm{U}_{\text {top }} \quad$ energy losses at the top of the collector, $\mathrm{W} /\left(\mathrm{m}^{2} . \mathrm{K}\right)$

$\mathrm{U}_{\text {base }} \quad$ energy losses at the base and the sides of the collector, $\mathrm{W} /\left(\mathrm{m}^{2} . \mathrm{K}\right)$

$\mathrm{U}_{\text {sides }} \quad$ energy the sides of the collector, $\mathrm{W} /\left(\mathrm{m}^{2} . \mathrm{K}\right)$

$U_{\text {tot }}$ global coefficient of thermal losses for the solar collectors, $\mathrm{w} /\left(\mathrm{m}^{2} . \mathrm{K}\right)$

$\mathrm{U}_{\mathrm{TA}} \quad$ global coefficient of thermal losses from the tank to the environment, $\mathrm{W} /\left(\mathrm{m}^{2} . \mathrm{K}\right)$

$\mathrm{U}_{\mathrm{f}} \quad$ global coefficient of thermal exchange between the surface and the fluid, $\mathrm{W} /\left(\mathrm{m}^{2} . \mathrm{K}\right)$

$\mathrm{W}$ distance between the tubes, $\mathrm{m}$

$\mathrm{V}_{\mathrm{v}} \quad$ average wind speed, $\mathrm{m} / \mathrm{s}^{2}$

$\mathrm{V}_{\text {consumption }}$ daily water consumption, $\mathrm{m}^{3}$

\section{Greek symbols}

$\begin{array}{ll}\alpha & \text { thermal diffusivity, } \mathrm{m}^{2} / \mathrm{s} \\ \varepsilon_{\mathrm{c}} & \text { emissivity of the glass } \\ \varepsilon_{\mathrm{p}} & \text { emissivity of the absorber surface } \\ \sigma & \text { Stefan-Boltzmann constant, } \mathrm{W} /\left(\mathrm{m}^{2} . \mathrm{K}^{4}\right) \\ \beta & \text { inclination of the collectors, degrees } \\ \mu_{\mathrm{it}} & \text { kinematic viscosity of the water within the } \\ \gamma & \text { tubes } \\ & \text { thickness of the solder at the surface-tube } \\ \nu & \text { junction, m } \\ \rho & \text { fluid kinematic viscosity, } \mathrm{m}^{2} / \mathrm{s}\end{array}$

\section{Subscripts}

j time interval of one hour

\section{INTRODUCTION}

The geographic location of Brazil provides the country with great potential for exploring renewable energy sources, especially solar energy (Pereira et al., 2012; Andrade et al., 2015; Silva; Marchi Neto and Seifert, 2016; Ferreira et al., 2018). Brazil is Latin America's largest renewable energy market (www.ren21.net, 2019), and the country is strongly committed to renewable energy, with continued investments in wind, solar, and hydropower capacity growth (Globaldata, 2018).

Solar energy has been the focus of several recent energy integration studies carried out in Brazil: Grilo et al. (2018) compared two energy supply options for a heat pump (solar energy vs. electric grid), Delgado et al. (2018) carried out an economic optimization that included photovoltaic solar energy a hospital, Carvalho and Delgado (2017) verified the potential of solar energy to reduce the carbon footprint of the Brazilian electricity matrix, and Carvalho, Delgado and Chacartegui (2016) employed life cycle assessment in the optimization of an energy supply system for a tertiary sector building.

The Brazilian industrial sector accounts for approximately one-third of the total national energy demand (Brazilian Company of Energy Survey, 2014), and the majority of this energy is employed in industrial processes that require electricity and thermal energy (process heat). Most industrial processes require temperatures between $60^{\circ} \mathrm{C}$ and $250^{\circ} \mathrm{C}$ (Kurup and Turchi, 2016), and solar industrial process heating is a clean and renewable energy option available in many countries of the world (Sharma et al., 2017a). With the use of wellestablished technologies, such as solar collectors and concentrators, it is possible to reach these temperature levels and satisfy industrial energy demands. Sharma et al. (2017a) present a detailed table that describes industrial processes with the corresponding range of process heating temperatures and heat transfer medium.

Industrial solar thermal systems can satisfy heat demands totally or partially, depending on the conditions established in the design of the system. Industrial water heating systems are constituted basically of a heating device that produces and supplies heat, and a distribution system that transfers thermal energy to the consumer center. Process heat can be produced directly (e.g., furnaces) or indirectly (e.g., heat pumps, solar collectors). Regarding the latter, steam and hot water are produced and employed in different applications such as drying, washing, cleaning, and bleaching processes of textile manufacturing.

As mentioned by Sharma et al. (2017a), there are several studies on the estimation of the potential of solar industrial process heating in different locations, considering specific processes and applications. Recent reviews on the application of solar energy for process heating have been published by Suresh and Rao (2017) and Kylili et al. (2018).

Already in 1989, the scope for solar energy utilization in the Indian textile industry was studied by Gupta (1989), followed by Abdel-Dayem and Mohamad (2001), who presented a feasibility study to obtain the potential of solar energy utilization in the textile industry. Prospects for solar water heating within the textile industries of Pakistan, Turkey, and China were the focuses of Muneer, Maubleu and Asif (2006), Muneer et al. (2008), and Jia et al. (2018), respectively. Considering the production of cotton textiles in India, the potential of solar industrial process heating to mitigate carbon emissions was reported by Sharma et al. (2017b), along with the specific incentives for the promotion of these systems (Sharma et al., 2018). Economic and environmental analyses were carried out for a biomass-solar hybrid system for the textile industry in India (Mahadevan and Salai, 2015), and the results of a solar process heat system installed at a textile company in southern Germany were monitored by Frey et al. (2015), while the viability of a concentrating photovoltaic/thermalenergy cogeneration system with storage for a textile industry application was described by Youssef et al. 
(2018). Finally, energy consumption and energy saving potentials in the clothing industry were reported by Çay (2018).

The first step in the design of solar water heating system is establishing conditions such as the required temperature range, followed by the location of the installation, analysis of local climatic conditions, and available investment/capital and type of technology. In residential and commercial applications, solar water heating systems can lead to significant reductions in electricity imports from the grid. In the industrial sector, besides this potential to reduce electricity consumption, these systems are a competitive alternative to conventional, fossil-fuel based heat generation systems. There are clear overall environmental advantages when fossil fuels are substituted by less carbon-intensive alternatives (Abrahao and Carvalho, 2017; Delgado et al., 2018; Araujo et al., 2018; Grilo et al., 2018).

Recognizing the importance of employing energy integration strategies in the synthesis and design of energy systems, the objective of this study is to report a step-by-step design guide for a solar water heating system, encompassing the selection of solar radiation data, determination of the hot water demand profile, climatic conditions and thermodynamic analysis. The thermodynamic analysis will consider the main thermal losses to ensure that hot water demands are met.

\section{MATERIALS AND METHODS}

Based on the minimum elements required by the Brazilian Association of Technical Standards (in Portuguese, ABNT) and using the plan proposed by the Brazilian Association of Cooling, Air Conditioning, Ventilation and Heating (in Portuguese, ABRAVA) as a guide (Fig. 1 (ABRAVA, 2008), this section provides the methodology for the design and technical feasibility analysis of the solar water heating system.

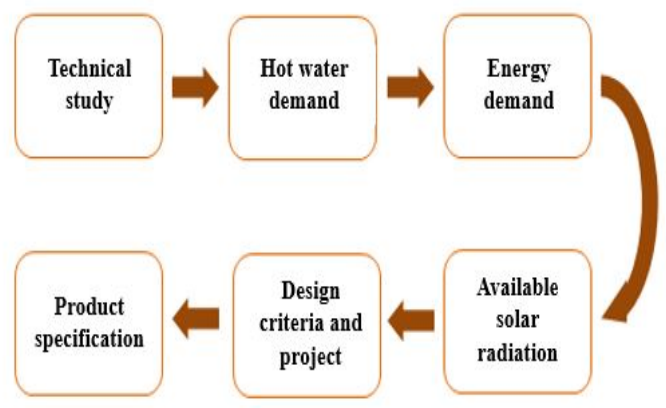

Figure 1. Design of a solar water heating system.

\section{Study Case}

A textile company is considered herein as a study case, located in João Pessoa (Northeast Brazil).
The company operates 24 hours a day, with programmed one-day breaks once a month for maintenance of the equipment. There is a 15-day recess: in December (7 days) and January (8 days). The company has a hot water demand of 230-300 $\mathrm{m}^{3} /$ month (approximately $10 \mathrm{~m}^{3} /$ day), which is equivalent to a consumption flow of approximately $0.12 \mathrm{~kg} / \mathrm{s}$ (temperature range between $50^{\circ} \mathrm{C}$ and $60^{\circ} \mathrm{C}$ ). Table 1 shows the average climatic data for the study site.

Table 1. Average monthly data for the city of João Pessoa (http://www.fau.usp.com, 2019).

\begin{tabular}{|c|c|c|c|c|c|c|}
\hline & $\begin{array}{c}\text { Average } \\
\text { temp. } \\
\left({ }^{\circ} \mathrm{C}\right)\end{array}$ & $\begin{array}{c}\text { Max. } \\
\text { temp. } \\
\left({ }^{\circ} \mathrm{C}\right)\end{array}$ & $\begin{array}{c}\text { Min. } \\
\text { temp. } \\
\left({ }^{\circ} \mathrm{C}\right)\end{array}$ & $\begin{array}{c}\text { Relative } \\
\text { humidity } \\
(\%)\end{array}$ & $\begin{array}{c}\text { Cloud } \\
\text { cover } \\
(0-10)\end{array}$ & $\begin{array}{c}\text { Wind } \\
\text { speed } \\
(\mathrm{m} / \mathrm{s})\end{array}$ \\
\hline Jan & 25.8 & 31.8 & 22.8 & 75 & 5.6 & 2.50 \\
\hline Feb & 25.2 & 30.5 & 22.6 & 75 & 5.8 & 2.50 \\
\hline Mar & 28.2 & 30 & 21.2 & 81 & 6.1 & 2.50 \\
\hline Apr & 25.5 & 29.8 & 22.9 & 79 & 6 & 2.50 \\
\hline May & 27 & 29.6 & 22.2 & 81 & 6.2 & 2.50 \\
\hline Jun & 26.2 & 28.3 & 21.8 & 81 & 6.1 & 2.50 \\
\hline Jul & 23.7 & 26.3 & 20.3 & 87 & 6 & 2.50 \\
\hline Aug & 25.4 & 27.8 & 21.7 & 75 & 5.2 & 2.50 \\
\hline Sep & 27.5 & 28.3 & 18.9 & 67 & 5.7 & 3.00 \\
\hline Oct & 27.7 & 29.3 & 23.3 & 73 & 5.1 & 2.50 \\
\hline Nov & 27 & 29.7 & 23.2 & 74 & 5.4 & 2.50 \\
\hline Dec & 24.1 & 30 & 23 & 74 & 5.3 & 2.00 \\
\hline $\begin{array}{c}\text { Annual } \\
\text { average }\end{array}$ & 26.1 & 29.3 & 21.9 & 76.8 & 5.7 & 2.50 \\
\hline
\end{tabular}

After the determination of the main climatic parameters, the next step is to estimate the available solar energy. There are software and spreadsheets freely available on the internet that, based on the geographical coordinates of a location, provide the monthly and annual average solar radiation available for different slopes and orientations. RadiaSol 2 (2010) software was utilized herein, which required the specifications of geographical location, slope, surface orientation, and albedo of the surfaces adjacent to the solar collectors. The roof albedo was considered as 0.6 , the solar collector inclination was $16^{\circ} \mathrm{N}$, and the orientation was $180^{\circ} \mathrm{N}$ (azimuth angle).

\section{Design of the Solar Hot Water System}

Brazilian standards (NBR 15669 - ABNT, 2008) present two options for the design of solar heating systems: the first is directed to single-family homes, and the second groups all remaining systems. This study will employ a methodology based on Duffie and Beckman (2014), but much more detailed than the $f$-Chart method, enabling the identification of thermal losses and therefore leading to a more realistic hot water system. A detailed description of each step necessary for the design of the solar hot water system follows:

- 1 1st Step: Determination of Storage Volume.

The storage volume can be calculated from Brazilian standards (ABNT, 2008): 


$$
\mathrm{V}_{\text {storage }}=\frac{\mathrm{V}_{\text {consumption }}-\left(\mathrm{T}_{\text {consumption }}-\mathrm{T}_{\text {amb }}\right)}{\left(\mathrm{T}_{\text {storage }}-\mathrm{T}_{\text {amb }}\right)}
$$

$\mathrm{V}_{\text {consumption }}$ is the daily water consumption, $\mathrm{m}^{3}$; $\mathrm{T}_{\text {consumption }}$ is the temperature of the water consumed, $\mathrm{K}$; $\mathrm{T}_{\text {storage }}$ is the water storage temperature ( $\left.\mathrm{T}_{\text {storage }}>\mathrm{T}_{\text {consumption }}\right)$, and $\mathrm{T}_{\mathrm{amb}}$ is the average annual ambient temperature at the site, $\mathrm{K}$.

- $2^{\text {nd }}$ Step: Determination of the Daily Demand of Useful Energy ( $\left.\mathrm{E}_{\text {useful }}\right)$

The daily demand of useful energy is the amount of energy required to heat the daily amount of water required (to its final use temperature). According to NBR 15669 (ABNT, 2008), $E_{\text {useful }}$ can be determined, in $\mathrm{kWh} / \mathrm{day}$, by:

$$
E_{\text {useful }}=\frac{V_{\text {storage }} \rho C_{P}\left(T_{\text {storage }}-T_{\text {amb }}\right)}{3600}
$$

$\rho$ is the specific mass of water, $\mathrm{kg} / \mathrm{m}^{3} ; \mathrm{C}_{\mathrm{p}}$ is the

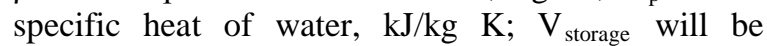
considered initially equal to the average daily consumption in $\mathrm{m}^{3} /$ day; $\mathrm{T}_{\text {storage }}$ will be initially considered equal to the temperature required for the hot water, $\mathrm{K}$; and $\mathrm{T}_{\mathrm{amb}}$ is the average ambient temperature (it is assumed that water is initially in thermodynamic equilibrium with the environment), $\mathrm{K}$.

Please note that Eq. (2) considered a constant temperature for the storage tank. It is important to highlight that this temperature will not be uniform, which makes it necessary to determine a mean temperature, $\mathrm{T}_{\text {storage }}$.

- $3^{\text {rd }}$ Step: Proposed solar water heating system without losses.

Figure 2 shows an outline of the proposed scheme for the solar heating system. The system has direct forced circulation (uses pumps to circulate the water), and the water that circulates in the collectors is the water consumed later.

An initial estimate must be made to determine the collector area. Average radiation values and local ambient temperature are utilized, and losses due to wind will not be considered. These initially calculated values will be used as the starting point for successive iterations, which will sequentially apply energy balances to the main components of the system.

Considering mass conservation and steady-state operation, the first law of thermodynamics is applied to each component of the system. Equations below represent energy balances for the solar collectors and for the storage tank, respectively:

$$
\begin{gathered}
0=\mathrm{IA}_{\mathrm{C}}-\mathrm{m}_{\mathrm{C}} \mathrm{C}_{\mathrm{P}}\left(\mathrm{T}_{\mathrm{C} 2}-\mathrm{T}_{\mathrm{C} 1}\right) \\
0=\mathrm{m}_{\mathrm{C}} \mathrm{C}_{\mathrm{P}}\left(\mathrm{T}_{\mathrm{C} 2}-\mathrm{T}_{\mathrm{C} 1}\right)-\mathrm{m}_{\text {consumption }} \mathrm{C}_{\mathrm{P}}\left(\mathrm{T}_{\text {consumption }}-\mathrm{T}_{\mathrm{amb}}\right)
\end{gathered}
$$

where I is the incident energy on the collector area, $\mathrm{MJ} / \mathrm{m}^{2} ; \mathrm{T}_{\mathrm{C} 1}$ and $\mathrm{T}_{\mathrm{C} 2}$ are the water temperature at the inlet and outlet of the solar collectors, $\mathrm{K} ; \mathrm{m}_{\mathrm{c}}$ is the mass of water in the collectors, $\mathrm{kg}$; and $\mathrm{m}_{\text {consumption }}$ is the daily water consumption, kg.

The storage tank presents stratified temperatures that vary between the inlet temperature and the consumption temperature (outlet). A dimensionless coefficient $\left(\mathrm{E}_{\text {storage }}\right)$ is applied to consider this effect: $\mathrm{E}_{\text {storage }}=0$ when $\mathrm{T}_{\text {storage }}=\mathrm{T}_{\mathrm{amb}}$ and $\mathrm{E}_{\text {storage }}=1$ when $\mathrm{T}_{\text {storage }}=\mathrm{T}_{\text {consumption }}$. This stratification occurs due to variations in the density of the water within the tank, due to differences in temperature.

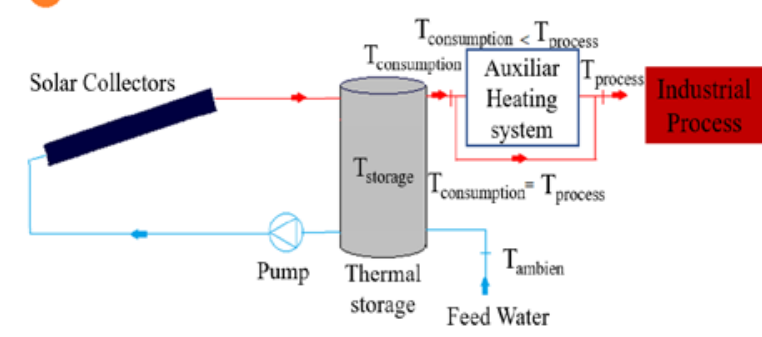

Figure 2. Proposed operating scheme for the solar hot water system.

The variation in $\mathrm{E}_{\text {storage }}$ can be calculated by:

$$
\mathrm{E}_{\text {storage }}=\frac{\mathrm{T}_{\text {consumption }}-\mathrm{T}_{\text {storage }}}{\mathrm{T}_{\mathrm{C} 2}-\mathrm{T}_{\text {storage }}}
$$

$\mathrm{E}_{\text {storage }}$ is the thermal stratification in the storage tank.

The energy balance considering the thermal stratification of the storage tank yields:

$$
\begin{aligned}
0=\mathrm{m}_{\mathrm{C}} \mathrm{C}_{\mathrm{P}} \mathrm{T}_{\mathrm{C} 2}+\mathrm{m}_{\text {consumption }} \mathrm{C}_{\mathrm{P}} \mathrm{T}_{\text {amb }} & \\
& =\left(\mathrm{m}_{\mathrm{C}}+\mathrm{m}_{\text {consumption }}\right) \mathrm{C}_{\mathrm{P}} \mathrm{T}_{\text {storage }}
\end{aligned}
$$

Therefore, the average tank storage temperature can be calculated as:

$$
\mathrm{T}_{\text {storage }}=\frac{\left(\mathrm{m}_{\mathrm{C}} \mathrm{T}_{\mathrm{C} 2}+\mathrm{m}_{\text {consumption }} \mathrm{T}_{\mathrm{amb}}\right)}{\left(\mathrm{m}_{\mathrm{C}}+\mathrm{m}_{\text {consumption }}\right)}
$$

The required collector area is determined by the ratio between the solar energy that is effectively used to heat the water in the system and the energy required to heat the water to the desired conditions:

$$
f=\frac{\mathrm{T}_{\text {storage }}-\mathrm{T}_{\mathrm{amb}}}{\mathrm{T}_{\text {consumption }}-\mathrm{T}_{\mathrm{amb}}}
$$

$f$ is an index that determines the solar contribution of the heating system and varies according to the configuration and location of the system.

The number of solar collectors required is calculated by: 


$$
\mathrm{N}_{\text {collectors }}=\frac{\mathrm{A}_{\mathrm{C}}}{\mathrm{A}_{\mathrm{tc}}}
$$

$A_{t c}$ is the area of the glass cover of the collector (also called "transparent area").

Considering Eqs. (3 - 9), following data is known: incident radiation on a tilted plane, efficiency of the solar collectors, inlet water temperature $\left(\mathrm{T}_{\mathrm{amb}}\right)$, required process temperature $\left(\mathrm{T}_{\text {process }}=60^{\circ} \mathrm{C}\right)$, energy consumption flow $\left(\mathrm{m}_{\text {cons }}=0.12 \mathrm{~kg} / \mathrm{s}\right)$, properties of the working fluid (water), and transparent area of the collectors. Eqs. (3 - 9) present the following unknowns: inlet temperature of the collectors $\left(\mathrm{T}_{\mathrm{c} 1}\right)$, outlet temperature of the collectors $\left(\mathrm{T}_{\mathrm{c} 2}\right)$, required mass flow in the collector bank, average storage tank temperature $\left(\mathrm{T}_{\text {storage }}\right)$, consumption temperature $\left(\mathrm{T}_{\text {consumption }}\right)$, and collector area $\left(\mathrm{A}_{\mathrm{c}}\right)$.

Equations 3 - 9 constitute a system of equations, which was solved with the Engineering Equation Solver (EES) software (2018), initially assuming a solar fraction of $80 \%$, and that $\mathrm{T}_{\mathrm{c} 1}$ is $20 \%$ higher than $\mathrm{T}_{\text {amb }}$ (thermal stratification in the storage tank).

After estimation of the initial collector area value, it is possible to estimate the solar fraction for all months of the year by solving the same system of equations in EES. The initial solar hot water system is determined within ideal conditions, but it is necessary to quantify and account for the losses that occur in the system and implement these in the final design.

The perfomance of any solar water system is affected by thermal losses. Agbo and Okoroigwe (2007) reported the effects of wind speed, number of glazing layers, ambient temperature, gap spacing between absorber plate and the glazing cover, tilt angle and the emissivity of the absorber plate on the overall heat-loss coefficient of a flat-plate collector.

Herein the losses can be divided into two main types, according to their location within the system: losses in the solar collectors and in the storage tank. The former are considered in the calculation of the collected useful energy. Fig. 3 shows the energy flow scheme in a collector.

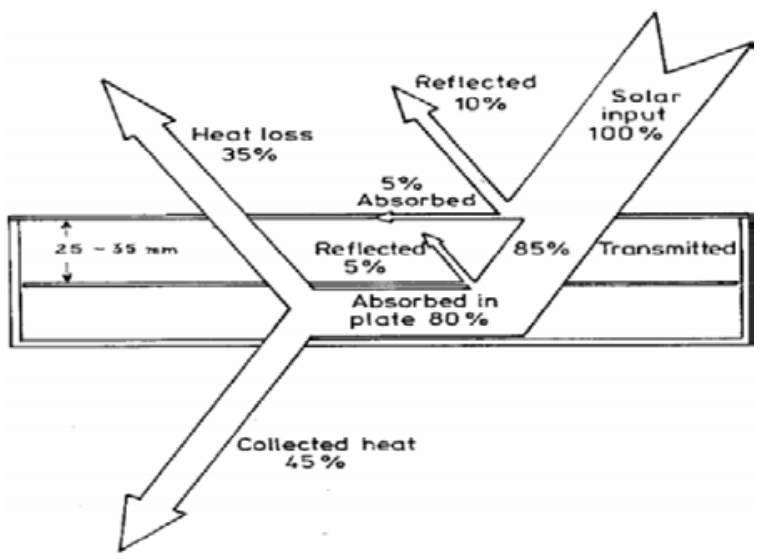

Figure 3. Energy flows in a flat plate solar collector (Struckmann, 2008).

\section{Determination of Collected Useful Energy}

The flat solar collector absorbs incident solar radiation, some of which is lost to the environment. The useful energy collected is the fraction of the energy that is effectively absorbed by the collector and converted into thermal energy (i.e., incident solar energy incident minus energy lost to the environment).

Complex iterative calculations are necessary to quantify the collected useful energy; Figure 4 shows the flowchart of the iterative method utilized herein. The initial estimate for the absorber surface temperature, $T_{a b s(j=1)}$, will consider that the surface temperature is initially the average ambient temperature plus $10 \mathrm{~K}$ (Duffie and Beckman, 2014).

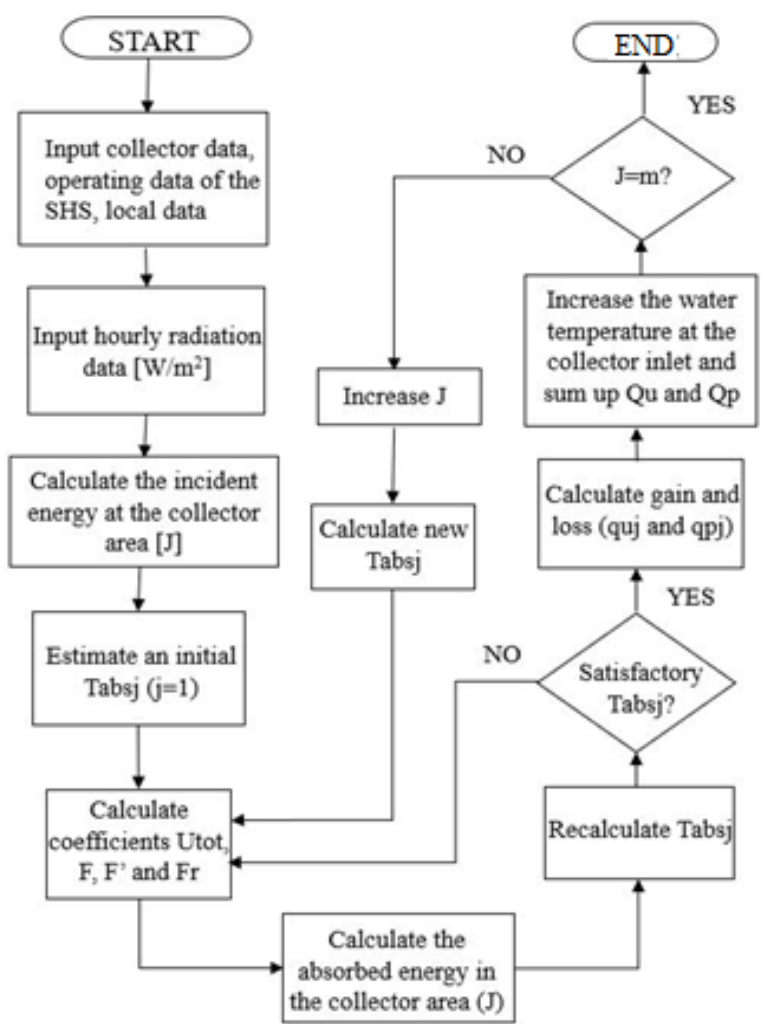

Figure 4. Flowchart for the calculation of the collected useful energy.

Calculation of the total solar collector heat loss coefficient, $U_{\text {tot }}$, collector fin efficiency factor, $F$, heat collection efficiency factor, $\mathrm{F}^{\prime}$, and heat removal factor, $F_{R}$, follow Duffie and Beckman (2014). Calculations considered steady-state operation, uniform temperatures of the glass cover and absorber surface throughout extension and thickness, onedimensional heat flows, and that radiation losses occur in the upper layers of the atmosphere.

Calculation of the incident energy on the collector area by hour (MJ/h) follows:

$$
I_{j}=3600 S_{j} A_{C}
$$


$\mathrm{S}_{\mathrm{j}}$ is the solar irradiance in one hour, $\mathrm{W} / \mathrm{m}^{2} \mathrm{~h}$.

The overall coefficient of thermal losses in the collector is obtained by adding the contribution of the different collector sections:

$$
\mathrm{U}_{\text {tot }}=\mathrm{U}_{\text {top }}+\mathrm{U}_{\text {base }}+\mathrm{U}_{\text {sides }}
$$

The energy losses at the top of the collector can be determined by:

$$
\begin{gathered}
\mathrm{U}_{\text {top }}=\left\{\frac{\mathrm{N}}{\frac{\mathrm{C}}{\mathrm{T}_{\mathrm{abs}}}\left[\mathrm{T}_{\mathrm{abs}}+\mathrm{T}_{\mathrm{amb}} / \mathrm{N}+\mathrm{z}\right]^{\mathrm{e}}}+\frac{1}{\mathrm{~h}_{\mathrm{ca}}}\right\}^{-1} \\
+\frac{\sigma\left(\mathrm{T}_{\mathrm{abs}}+\mathrm{T}_{\mathrm{amb}}\right)\left(\mathrm{T}_{\mathrm{abs}}^{2}+\mathrm{T}_{\mathrm{amb}}^{2}\right)}{\left(\varepsilon_{\mathrm{p}}+0.00591 \mathrm{Nh}_{\mathrm{ca}}\right)^{-1}+\left(2 \mathrm{~N}+\mathrm{z}-1+0.133 \varepsilon_{\mathrm{p}} / \varepsilon_{\mathrm{c}}\right)-\mathrm{N}} \\
\mathrm{C}=520\left(1-0.000051 \beta^{2}\right) \\
\mathrm{h}=0.430\left(1-\frac{100}{\mathrm{~T}_{\mathrm{abs}}}\right) \\
\mathrm{z}=\left(1+0.089 \mathrm{~h}_{\mathrm{ca}}-0.1166 \mathrm{~h}_{\mathrm{ca}} \varepsilon_{\mathrm{p}}\right)(1+0.07866 \mathrm{~N})
\end{gathered}
$$

$\mathrm{N}$ is the number of glass covers in the collector; $\varepsilon_{\mathrm{p}}$ and $\varepsilon_{\mathrm{c}}$ are the emissivities of the absorber surface and of the glass, respectively; $\sigma$ is the Stefan-Boltzmann constant, $\mathrm{W} /\left(\mathrm{m}^{2} \cdot \mathrm{K}^{4}\right) ; \mathrm{T}_{\mathrm{abs}}$ is the temperature of the absorber surface, $\mathrm{K} ; \mathrm{V}_{\mathrm{v}}$ is the average wind speed, $\mathrm{m} / \mathrm{s} ; h_{\text {ca }}$ is the convective coefficient between the glass cover of the collector and the air, $\mathrm{W} /\left(\mathrm{m}^{2} . \mathrm{K}\right)$; and $\beta$ is the inclination of the collectors.

The energy losses at the base and the sides of the collector are determined by:

$$
\begin{gathered}
\mathrm{U}_{\text {base }}=\frac{\mathrm{k}_{\mathrm{i}}}{\mathrm{l}_{\mathrm{i}}} \\
\mathrm{U}_{\text {sides }}=\frac{\mathrm{A}_{\text {sides }}}{\mathrm{A}_{\text {col }}} \mathrm{U}_{\text {base }}
\end{gathered}
$$

where $k_{i}$ and $l_{i}$ are the thermal conductivity and thickness of the thermal insulation, respectively, and $\mathrm{A}_{\text {sides }}$ and $\mathrm{A}_{\text {col }}$ are the lateral area and the total area of the collector, respectively.

The collector fin efficiency factor for straight fins, F, is determined by:

$$
F=\frac{\operatorname{tgh}\left(m \frac{\left(W-D_{e}\right)}{2}\right)}{m \frac{\left(W-D_{e}\right)}{2}}
$$

$$
\mathrm{m}=\sqrt{\frac{\mathrm{U}_{\mathrm{tot}}}{\mathrm{kt}}}
$$

$\mathrm{t}$ and $\mathrm{k}$ are the thickness and thermal conductivity of the absorber surface, respectively, $\mathrm{W}$ is the distance between the tubes; and $D_{e}$ is the outer diameter of the tubes.

The heat collection efficiency factor, F', is determined by:

$$
\begin{gathered}
F^{\prime}=\left(\frac{1 / U_{\text {tot }}}{W\left(D_{e}+\left(W-D_{e}\right) F\right)}\right) U_{f} \\
U_{f}=\frac{1}{\frac{1}{h_{i} \pi D_{i}}+\frac{\gamma}{k_{b} b}}
\end{gathered}
$$

$U_{f}$ is the global coefficient of thermal exchange between the surface and the fluid, $h_{i}$ is the convection coefficient internal to the tubes, $\mathrm{b}$ and $\mathrm{k}_{\mathrm{b}}$ are the width of the surface-tube junction and its thermal conductivity, respectively, and $\gamma$ is the thickness of the solder at the surface-tube junction.

The internal convection coefficient in the tubes is determined by calculating the Nusselt number, in function of the Reynolds number, given by:

$$
\operatorname{Re}=\frac{4\left(\frac{\mathrm{m}_{\mathrm{C}}}{\mathrm{N}_{\mathrm{t}}}\right)}{\pi \mathrm{D}_{\mathrm{i}} \mu_{\mathrm{it}}}
$$

Re is the Reynolds number, $\mathrm{m}_{\mathrm{c}}$ is the mass flow in a collector, $\mathrm{N}_{\mathrm{t}}$ is the number of tubes in the collector, $D_{i}$ the inner diameter of the tubes, and $\mu_{i t}$ is the kinematic viscosity of the water within the tubes.

Once the Reynolds number is known and flow is characterized as laminar $(\operatorname{Re}<2300)$ or turbulent ( $\operatorname{Re}>4000$ ), a suitable correlation can be selected for calculating the Nusselt number. Herein $\mathrm{Re} \geq 2300$ was considered for turbulent flow.

Considering that the thermal flow on the surface of the tubes is constant, the correlations adopted herein to calculate the Nusselt number for laminar or turbulent flow were:

$$
\begin{gathered}
\mathrm{Nu}=4.36 \\
\mathrm{Nu}=\frac{\left(\mathrm{f}_{\mathrm{a}} / 8\right)(\mathrm{Re}-1000) \mathrm{Pr}}{1+12.7\left(\mathrm{f}_{\mathrm{a}} / 8\right)^{\frac{1}{2}}\left(\mathrm{Pr}^{\frac{2}{3}}-1\right)}
\end{gathered}
$$

$\mathrm{f}_{\mathrm{a}}$ is the friction factor of the flow inside the tubes, and $\operatorname{Pr}$ is the Prandtl number of the water at the average water temperature in the collectors. Equation 25 was formulated by Gnielinski (1976) and is valid for calculating the Nusselt number for flows characterized as transient or turbulent $(\operatorname{Re}>2300)$.

The friction factor of the water flow inside the 
tubes is calculated by (for $\operatorname{Re}<3000$ ):

$$
f_{a}=0.316 \operatorname{Re}^{-1 / 4}
$$

For $\operatorname{Re} \geq 3000$ :

$$
f_{a}=(0.790 \ln (\operatorname{Re})-1.64)^{-2}
$$

Once the Nusselt number is calculated, the convection coefficient of the water flow inside the collector tubes is defined by isolating $\mathrm{h}_{\mathrm{t}}$ :

$$
\mathrm{Nu}=\frac{\mathrm{h}_{\mathrm{t}} \mathrm{D}_{\mathrm{i}}}{\mathrm{k}_{\mathrm{c}}}
$$

The heat removal factor, $F_{R}$, is calculated as:

$$
F_{R}=\frac{m C_{P}}{A_{C} U_{\text {tot }}}\left[1-e^{\frac{-A_{C} U_{\text {tof }} \mathrm{F}^{\prime}}{m C_{P}}}\right]
$$

The energy absorbed per hour in the collector area is calculated as:

$$
\mathrm{Q}_{\mathrm{u}}=3600 \mathrm{~A}_{\mathrm{C}} \mathrm{F}_{\mathrm{R}}\left(\mathrm{S}-\mathrm{U}_{\text {tot }}\left(\mathrm{T}_{\mathrm{abs}}-\mathrm{T}_{\mathrm{amb}}\right)\right)
$$

After calculating the values of the coefficients for the initially estimated temperature of the absorber surface, it is necessary to correct $\mathrm{T}_{\mathrm{abs}}$ through an iterative process, until the relative difference between the new value and previous $T_{a b s}$ values is less than 1 $\times 10^{-4}$.

$$
\mathrm{T}_{\mathrm{abs}}=\mathrm{T}_{\mathrm{f} 1}+\left(\frac{\mathrm{Q}_{\mathrm{u}}}{\mathrm{A}_{\mathrm{C}} \mathrm{F}_{\mathrm{R}} \mathrm{U}_{\text {tot }}}\right)\left(1-\mathrm{F}_{\mathrm{R}}\right)
$$

With the corrected $T_{\text {abs }}$ value, coefficients $U_{\text {tot }}$, $\mathrm{F}, \mathrm{F}^{\prime}$ and $\mathrm{F}_{\mathrm{R}}$ are then recalculated from Eqs. 11 to 29, and the thermal energy gains and losses in the collectors are determined.

The total useful energy and energy losses are calculated by:

$$
\begin{aligned}
& \mathrm{Q}_{\text {tot }}=3600 \sum_{\mathrm{j}=1}^{\mathrm{m}} \mathrm{Q}_{\mathrm{uj}} \\
&= 3600 \sum_{\mathrm{j}=1}^{\mathrm{m}} \mathrm{F}_{\mathrm{Rj}}\left[\mathrm{S}_{\mathrm{j}}-\mathrm{A}_{\mathrm{C}} \mathrm{U}_{\text {totj }}\left(\mathrm{T}_{\mathrm{C} 1 \mathrm{j}}-\mathrm{T}_{\mathrm{ambj}}\right)\right] \\
& \mathrm{mC}_{\mathrm{P}}\left(\mathrm{T}_{\mathrm{mf}(\mathrm{j}+1)}-\mathrm{T}_{\mathrm{mf}(\mathrm{j})}\right)=\mathrm{Q}_{\mathrm{uj}}-\mathrm{Q}_{\mathrm{pj}}
\end{aligned}
$$

and $\mathrm{T}_{\mathrm{mf}}$ is the average temperature of the fluid in the collectors:

$$
\mathrm{T}_{\mathrm{mf}}=\mathrm{T}_{\mathrm{f} 1}+\left(\frac{\mathrm{Q}_{\mathrm{u}}}{\mathrm{A}_{\mathrm{C}} \mathrm{F}_{\mathrm{R}} \mathrm{U}_{\mathrm{tot}}}\right)\left(1-\frac{\mathrm{F}_{\mathrm{R}}}{\mathrm{F}^{\prime}}\right)
$$

For the solution of Eq. (25) at $\mathrm{j}=1, \mathrm{~T}_{\mathrm{f} 1}$ will be considered equal to $\mathrm{T}_{\mathrm{amb}}$. For $\mathrm{j}>1, \mathrm{~T}_{\mathrm{f} 1}$ is the average ambient temperature and the average fluid temperature at the previous instant, $\mathrm{T}_{\mathrm{mf}(\mathrm{j}-1)}$.

\section{Determination of Storage Losses}

The storage tank is insulated, but as the water temperature in the tank is higher than ambient temperature, there will be thermal energy losses (variation in the internal energy stored in the tank) (ABNT, 2013).

Equation 35 represents the internal energy storage capacity, without consideration of the effects of thermal stratification in the tanks:

$$
\mathrm{Q}_{\text {storage }}=\mathrm{m}_{\text {storage }} \mathrm{C}_{\mathrm{P}} \Delta \mathrm{T}_{\text {storage }}
$$

$\mathrm{m}_{\text {storage }}$ is the mass of the stored liquid, $\mathrm{Cp}$ is the specific heat of the stored liquid, and $\Delta \mathrm{T}_{\text {storage }}$ is the variation in the average temperature of the stored liquid in a given time interval.

$$
\begin{aligned}
& \mathrm{m}_{\text {storage }} \mathrm{C}_{\mathrm{P}} \Delta \mathrm{T}_{\text {storage }} \\
& =\mathrm{Q}_{\mathrm{u}}-\mathrm{E}_{\text {useful }}-3600 \mathrm{U}_{\mathrm{TA}} \mathrm{A}_{\mathrm{TA}}\left(\mathrm{T}_{\text {storage }}-\mathrm{T}_{\text {amb }}\right)
\end{aligned}
$$

Equation 36 is obtained from an energy balance. $\mathrm{Q}_{\mathrm{u}}$ is the thermal energy originating from the collectors, $\mathrm{E}_{\text {useful }}$ is the energy demand of the textile process, and $U_{\mathrm{TA}}$ and $\mathrm{A}_{\mathrm{TA}}$ are the global coefficients of thermal losses to the environment and the external area of the tank, respectively.

Integration of Eq. (36) concerning time, considering a time interval of 1 hour, yields:

$$
\begin{gathered}
\mathrm{T}_{\text {storage }(\mathrm{j})}=\mathrm{T}_{\text {storage }(\mathrm{j}-1)}+\frac{\Delta \mathrm{t}}{\mathrm{m}_{\text {storage }} \mathrm{C}_{\mathrm{P}}} \\
{\left[\mathrm{Q}_{\mathrm{u}} \mathrm{E}_{\text {useful }}-3600 \mathrm{U}_{\mathrm{TA}} \mathrm{A}_{\mathrm{TA}}\left(\mathrm{T}_{\text {storage }(\mathrm{j}-1)}-\mathrm{T}_{\text {amb }}\right)\right]}
\end{gathered}
$$

Solution of Eq. (37) considers that, for $\mathrm{j}=1$, $\mathrm{T}_{\text {storage(j-1) }}=\mathrm{T}_{\mathrm{amb}}+20$; for $\mathrm{j}>1, \mathrm{~T}_{\text {storage(j-1) }}$ will be the storage temperature calculated for the previous hour (j).

\section{Solar Fraction of the Solar Hot Water System}

After determination of the losses in the collectors and storage tank, the solar fraction can be determined by:

$$
f=\frac{\mathrm{E}_{\text {useful }}+\mathrm{Q}_{\mathrm{u}}}{\mathrm{E}_{\text {useful }}}
$$

\section{RESULTS AND DISCUSSION}

Table 2 shows the average monthly irradiance $\left(\mathrm{W} / \mathrm{m}^{2}\right)$ for each month of the year, calculated from the hourly irradiance values provided by RadiaSol 2 . 
These values are important to determine the incident radiation on the surface and its variation throughout the day. The monthly average hourly irradiance $\left(\mathrm{W} / \mathrm{m}^{2}\right)$ will be used to design the system.

Table 2. Monthly Average Daily Irradiance $\left(\mathrm{W} / \mathrm{m}^{2}\right)$ on a tilted plane $\left(16^{\circ} \mathrm{N}\right)$ for the city of João Pessoa, Brazil.

\begin{tabular}{|c|c|c|c|c|}
\hline \multicolumn{5}{|c|}{ Average daily irradiance (W/m $\mathbf{2})$} \\
\hline Month & Global & Direct & Diffuse & Tilted $\left(16^{\circ}\right)$ \\
\hline Jan & 297 & 161 & 154 & 316 \\
\hline Feb & 317 & 181 & 141 & 323 \\
\hline Mar & 305 & 150 & 145 & 296 \\
\hline Apr & 279 & 134 & 118 & 252 \\
\hline May & 280 & 127 & 111 & 239 \\
\hline Jun & 237 & 97 & 99 & 197 \\
\hline Jul & 253 & 115 & 94 & 210 \\
\hline Aug & 299 & 143 & 118 & 263 \\
\hline Sep & 315 & 165 & 130 & 296 \\
\hline Oct & 356 & 216 & 138 & 355 \\
\hline Nov & 367 & 244 & 139 & 383 \\
\hline Dec & 351 & 234 & 140 & 375 \\
\hline Annual & 302 & 156 & 134 & 296 \\
\hline
\end{tabular}

\section{Design of the Solar Hot Water System}

The calculated storage volume was $7.70 \mathrm{~m}^{3}$. The hot water demand is constant and continuous (24 hours a day, no interruptions) while the availability of solar energy is variable, and therefore a conservative approach is to double the storage volume (i.e., $16 \mathrm{~m}^{3}$ is considered to guarantee a higher share of contribution by the solar hot water system). Calculations took into account a storage temperature of $70^{\circ} \mathrm{C}$.

The monthly useful energy demand of the system can be obtained by multiplying the result of Eq. (2) by the number of days per month during which the system is operating (Tab. 3). In this case, the ambient temperature considered for each month is the average annual temperature (Tab. 1).

Table 3. Monthly Energy Demand for Water Heating (10,000 L/day).

\begin{tabular}{|l|l|l|}
\hline Month & $\begin{array}{l}\text { Operating days } \\
\text { (number) }\end{array}$ & $\begin{array}{l}\text { Euseful } \\
\text { (kWh/month) }\end{array}$ \\
\hline Jan & 23 & 9229.44 \\
\hline Feb & 28 & $11,235.84$ \\
\hline Mar & 30 & $12,038.40$ \\
\hline Apr & 29 & $11,637.12$ \\
\hline May & 30 & $12,038.40$ \\
\hline Jun & 29 & $11,637.12$ \\
\hline Jul & 30 & $12,038.40$ \\
\hline Aug & 30 & $12,038.40$ \\
\hline Sep & 29 & $11,637.12$ \\
\hline Oct & 30 & $12,038.40$ \\
\hline Nov & 29 & $11,637.12$ \\
\hline Dec & 24 & 9630.72 \\
\hline Annual Total & 341 & 9229.44 \\
\hline
\end{tabular}

From Tab. 3 it can be verified that the highest monthly energy demand was $12,038.40 \mathrm{kWh} / \mathrm{month}$ (occurring in March, May, July, August, and September), and therefore this value will be utilized in the following calculations.

As the textile industry operates continuously, the daily energy demand is independent of the month. Dividing the monthly useful energy demand by the number of operation days per month yields 401.28 kWh/day.

\section{Selection of Solar Collector}

Once the availability of solar radiation is estimated and the hot water requirements are known, equipment can be selected. Solar water heating is a technology that is simple to adopt and basically consists of flat-plate collectors, the flow pipe network and the water storage tank. Due to its widespread availability in Brazil, the solar collector adopted herein was the flat solar collector S-81, manufactured by Solar Tech (2018). Table 4 shows the technical specifications of the collector, and its efficiency is provided by:

$$
n=62.1-513.6\left(\frac{\mathrm{T}_{\mathrm{C} 2}-\mathrm{T}_{\mathrm{amb}}}{\mathrm{I}}\right)
$$

Table 4. Parameters of the Flat Solar Collector S-81.

\begin{tabular}{|c|c|}
\hline \multicolumn{2}{|c|}{ Technical Specifications } \\
\hline External Area & $1.78 \mathrm{~m}^{2}$ \\
\hline Transparent Area & $1.72 \mathrm{~m}^{2}$ \\
\hline Dry Collector Weight & $29 \mathrm{~kg}$ \\
\hline Max Operating & $250 \mathrm{kPa}$ \\
\hline Working Fluid & Water \\
\hline Thermal Efficiency & $51.8 \%$ \\
\hline $\mathbf{F}_{\mathbf{R}}(\boldsymbol{\tau} \boldsymbol{\alpha})$ & 0.645 \\
\hline $\mathbf{F}_{\mathbf{R}}\left(\mathbf{U}_{\mathbf{l}}\right)$ & 5.334 \\
\hline
\end{tabular}

\section{Solar Hot Water System Without Losses}

Table 5 shows the results obtained when disregarding the losses of the system. These values are initial estimates, a starting point for the calculation of monthly mean values and for the final design. The only loss considered at this point is the efficiency curve provided by the manufacturer.

Table 5. Solar hot water system without losses: results of the system of equations.

\begin{tabular}{|c|c|c|c|c|c|c|c|}
\hline $\mathbf{T}_{\mathbf{c} 1}$ & $\mathbf{T}_{\mathbf{c} 2}$ & $\mathbf{m}_{\mathbf{c}}$ & $\mathbf{T}_{\text {storage }}$ & $\mathbf{T}_{\text {consumption }}$ & $\mathbf{A}_{\mathbf{c}}$ & $\mathbf{N}_{\text {colletors }}$ & $\mathbf{f}$ \\
\hline $\mathbf{3 1 . 3 2}^{\circ} \mathbf{C}$ & $61.59^{\circ} \mathrm{C}$ & $\begin{array}{c}0.1075 \\
\mathrm{~kg} / \mathrm{s}\end{array}$ & $42.87^{\circ} \mathrm{C}$ & $53.22^{\circ} \mathrm{C}$ & $\begin{array}{c}88.79 \\
\mathrm{~m}^{2}\end{array}$ & 51.62 & 0.80 \\
\hline
\end{tabular}

The manufacturer-recommended volumetric flow rate in the collectors is $70 \mathrm{~L} / \mathrm{h}$, which is equivalent to approximately $0.02 \mathrm{~kg} / \mathrm{s}$. Thus, to reach the mass flow required by the system, the collectors must be positioned in at least five parallel sets.

Due to safety reasons, the number of collectors 
will be rounded to the next higher multiple of five, that is, 55 collectors will be used (five parallel sets of 11 collectors connected in series), resulting in a collector area of approximately $95 \mathrm{~m}^{2}$.

Once the number of collectors and mass flow have been defined, monthly solar fraction data were obtained for the system by considering the monthly averages of solar radiation and ambient temperature, while disregarding losses (Tab. 6).

Table 6. Solar hot water system without losses: results of the system of equations when using monthly average values.

\begin{tabular}{|c|c|c|c|c|c|}
\hline & $\mathbf{F}$ & $\mathbf{T}_{\mathbf{c 1}}\left({ }^{\circ} \mathbf{C}\right)$ & $\mathbf{T}_{\mathbf{c 2}}\left({ }^{\circ} \mathbf{C}\right)$ & $\mathbf{T}_{\text {storage }}\left({ }^{\circ} \mathbf{C}\right)$ & $\mathbf{T}_{\text {cons }}\left({ }^{\circ} \mathbf{C}\right)$ \\
\hline Jan & 0.9020 & 26.67 & 63.69 & 43.02 & 56.65 \\
\hline Feb & 0.9061 & 26.09 & 63.93 & 42.80 & 56.73 \\
\hline Mar & 0.8303 & 26.02 & 63.69 & 41.33 & 54.10 \\
\hline Apr & 0.7131 & 26.19 & 55.72 & 39.23 & 50.10 \\
\hline May & 0.7070 & 27.66 & 55.66 & 40.03 & 50.33 \\
\hline Jun & 0.5690 & 26.74 & 49.82 & 36.94 & 45.43 \\
\hline Jul & 0.5648 & 24.28 & 48.88 & 35.15 & 44.20 \\
\hline Aug & 0.7420 & 26.13 & 56.93 & 39.73 & 51.07 \\
\hline Sep & 0.8891 & 28.32 & 62.99 & 43.63 & 56.40 \\
\hline Oct & 1073 & 28.68 & 70.27 & 47.05 & 62.32 \\
\hline Nov & 1133 & 28.06 & 72.92 & 47.87 & 64.39 \\
\hline Dec & 10200 & 25.13 & 69.06 & 44.54 & 58.71 \\
\hline
\end{tabular}

The solar system is least efficient in June and July, but it can supply more than half of the total energy demand in each month. The results obtained with a numerical routine developed in MATLAB software (2018) are presented in the following section.

\section{Collected Useful Energy}

Table 7 shows the average values of the collected useful energy, as computed from the annual average hourly data.

Table 7. Collected useful energy and annual average values.

\begin{tabular}{|l|c|c|c|c|c|c|c|c|c|}
\hline $\mathbf{j}$ & $\begin{array}{c}\mathbf{S} \\
{\left[\mathbf{W} / \mathbf{m}^{2}\right]}\end{array}$ & $\mathbf{I}[\mathbf{M J}]$ & $\begin{array}{c}\text { Tabs } \\
{\left[{ }^{\circ} \mathbf{C}\right]}\end{array}$ & $\begin{array}{c}\mathbf{U t o t} \\
{\left[\mathbf{W} / \mathbf{m}^{2} \mathbf{K}\right]}\end{array}$ & $\begin{array}{c}\mathbf{T f m} \\
{\left[{ }^{\circ} \mathbf{C}\right]}\end{array}$ & $\begin{array}{c}\mathbf{Q u} \\
{[\mathbf{M J}]}\end{array}$ & $\begin{array}{c}\mathbf{Q p} \\
{[\mathbf{M J}]}\end{array}$ & $\begin{array}{c}\mathbf{Q t o t} \\
{[\mathbf{M J}]}\end{array}$ & $\begin{array}{c}\mathbf{Q p t} \\
{[\mathbf{M J}]}\end{array}$ \\
\hline $\mathbf{6}$ & 62.00 & 21.1147 & 23.99 & 4.8347 & 23.54 & 17.99 & 3.13 & 17.99 & 3.13 \\
\hline $\mathbf{7}$ & 214.00 & 72.8798 & 30.27 & 4.5158 & 28.41 & 72.82 & 0.06 & 90.81 & 3.19 \\
\hline $\mathbf{8}$ & 400.50 & 136.394 & 39.18 & 5.3848 & 35.72 & 135.82 & 0.58 & 226.62 & 3.76 \\
\hline $\mathbf{9}$ & 531.00 & 180.837 & 47.49 & 5.8991 & 42.93 & 179.36 & 1.47 & 405.99 & 5.24 \\
\hline $\mathbf{1 0}$ & 672.00 & 228.856 & 56.09 & 6.2315 & 50.32 & 226.48 & 2.38 & 632.47 & 7.62 \\
\hline $\mathbf{1 1}$ & 748.50 & 254.909 & 62.69 & 6.5205 & 56.29 & 251.53 & 3.38 & 884.00 & 10.99 \\
\hline $\mathbf{1 2}$ & 744.00 & 253.376 & 65.98 & 6.7215 & 59.64 & 249.22 & 4.16 & 1133.21 & 15.15 \\
\hline $\mathbf{1 3}$ & 662.00 & 225.450 & 65.47 & 6.8170 & 59.85 & 220.95 & 4.50 & 1354.16 & 19.66 \\
\hline $\mathbf{1 4}$ & 559.50 & 190.543 & 61.76 & 6.8037 & 57.02 & 185.99 & 4.55 & 1540.15 & 24.21 \\
\hline $\mathbf{1 5}$ & 386.00 & 131.456 & 54.26 & 6.6961 & 51.02 & 127.30 & 4.15 & 1667.46 & 28.36 \\
\hline $\mathbf{1 6}$ & 231.00 & 78.6694 & 45.82 & 6.4672 & 43.90 & 75.41 & 3.25 & 1742.87 & 31.61 \\
\hline $\mathbf{1 7}$ & 64.50 & 21.9661 & 36.46 & 6.1807 & 35.96 & 19.68 & 2.28 & 1762.56 & 33.90 \\
\hline
\end{tabular}

An important observation regarding the findings is the behavior of the global coefficient of thermal losses, $U_{\text {tot }}$, relative to the temperature of the absorber surface, $\mathrm{T}_{\mathrm{abs}}$. As the temperature of the absorber surface increases, the thermal losses from the collectors to the environment increase as well, due to the higher temperature difference collectorambient.

The values of the incident energy I, collected energy Qu, and lost energy Qp found in Tab. 7 are shown in Fig. 6. It is observed that the fraction of the solar energy lost to the environment in the form of heat is proportional to the solar energy incident on the collector area and to the solar energy that is effectively absorbed by the collectors.

Another important feature of Fig. 5 is the behavior of the collected energy with respect to time. As with the incidence of solar radiation, the collected energy increases from early morning until reaching its maximum value close to solar noon and then decreases proportionately until the end of the day.

Regarding the average temperature of the fluid in the collector, $\mathrm{T}_{\mathrm{mf}}$, its behavior is proportional to the incidence of solar radiation and varies considerably from hour to hour during the day, with progressively increasing thermal gain. At 17:00h, with a solar incidence of $64.5 \mathrm{~W} / \mathrm{m}^{2}$, an average fluid temperature of $40.7^{\circ} \mathrm{C}$ is reached.

Figure 6 shows the monthly variation in the fractions of incident, collected and lost energy in the collecting area. These values were obtained from the sum of the hourly data calculated for each month of the year.

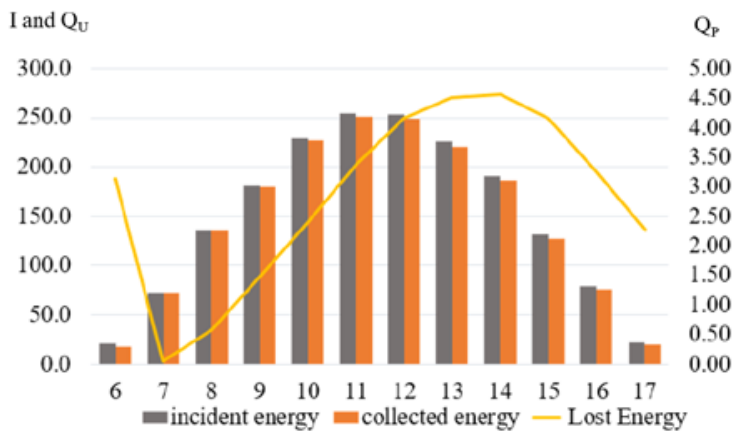

Figure 5. Fractions of collected and lost energy relative to incident energy in the collector area (MJ).

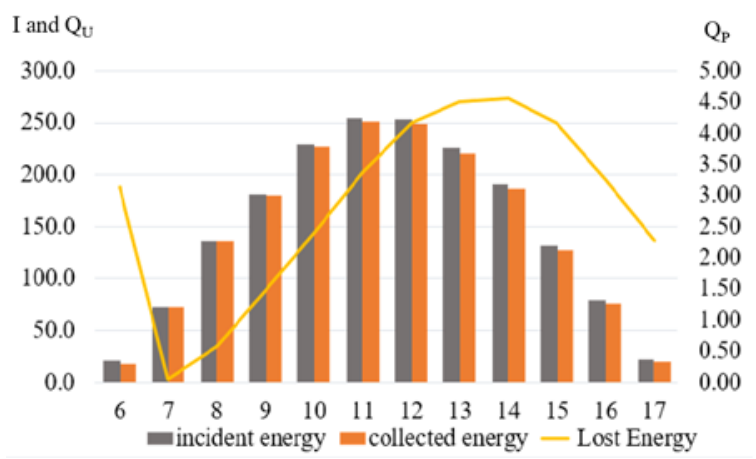

Figure 6. Monthly behavior of incident, collected and 
lost energy fractions of the solar hot water system.

\section{Storage Losses}

Before storage losses are calculated, it is necessary to select a specific tank, with the previously defined storage volume $\left(16 \mathrm{~m}^{3}\right)$. Eight 2000-L tanks were selected from Solar Tech (2008), with specifications shown in Tab. 8.

Table 8. Storage tank technical specifications (www.solartechbr.com.br, 2018).

\begin{tabular}{|c|c|}
\hline \multicolumn{2}{|c|}{ Boiler 2000-L - SolarTech } \\
\hline Length & $2.65 \mathrm{~m}$ \\
\hline Width & $1.07 \mathrm{~m}$ \\
\hline Height & $1.12 \mathrm{~m}$ \\
\hline Thermal insulation & Expanded polystyrene \\
\hline Insulation thickness & $0.05 \mathrm{~m}$ \\
\hline
\end{tabular}

For the coefficient of global thermal losses between the tank and the environment, it is assumed that the tanks will be installed in a closed environment without wind incidence. The thermal resistance method provided a value of approximately $1.1 \mathrm{~W} / \mathrm{m}^{2} \mathrm{~K}$ for this coefficient.

Table 9 shows the mean values obtained in the calculation of storage losses considering the annual average hourly data for tanks connected in parallel.

Table 9. Average annual hourly storage losses.

\begin{tabular}{|c|c|c|c|c|}
\hline $\mathbf{J}$ & $\mathbf{Q u}[\mathbf{M J}]$ & Tstorage $\left[{ }^{\circ} \mathbf{C}\right]$ & $\mathbf{Q p a}[\mathbf{M J}]$ & Qstorage [MJ] \\
\hline $\mathbf{1}$ & 0 & 40.90 & 6.50 & -66.70 \\
\hline $\mathbf{2}$ & 0 & 39.91 & 6.18 & -66.37 \\
\hline $\mathbf{3}$ & 0 & 38.92 & 5.86 & -66.05 \\
\hline $\mathbf{4}$ & 0 & 37.94 & 5.54 & -65.73 \\
\hline $\mathbf{5}$ & 0 & 36.97 & 4.92 & -65.12 \\
\hline $\mathbf{6}$ & 17.99 & 36.27 & 4.28 & -46.48 \\
\hline $\mathbf{7}$ & 72.82 & 36.39 & 4.38 & 8.25 \\
\hline $\mathbf{8}$ & 135.82 & 37.46 & 4.10 & 71.53 \\
\hline $\mathbf{9}$ & 179.36 & 39.18 & 4.12 & 115.05 \\
\hline $\mathbf{1 0}$ & 226.48 & 41.61 & 4.03 & 162.26 \\
\hline $\mathbf{1 1}$ & 251.53 & 44.40 & 4.49 & 186.85 \\
\hline $\mathbf{1 2}$ & 249.22 & 47.15 & 5.07 & 183.95 \\
\hline $\mathbf{1 3}$ & 220.95 & 49.47 & 5.81 & 154.95 \\
\hline $\mathbf{1 4}$ & 185.99 & 51.25 & 6.72 & 119.08 \\
\hline $\mathbf{1 5}$ & 127.30 & 52.14 & 7.63 & 59.48 \\
\hline $\mathbf{1 6}$ & 75.41 & 52.25 & 8.24 & 6.98 \\
\hline $\mathbf{1 7}$ & 19.68 & 51.51 & 8.60 & -49.11 \\
\hline $\mathbf{1 8}$ & 0 & 50.48 & 8.98 & -69.17 \\
\hline $\mathbf{1 9}$ & 0 & 49.45 & 8.67 & -68.87 \\
\hline $\mathbf{2 0}$ & 0 & 48.42 & 8.67 & -68.86 \\
\hline $\mathbf{2 1}$ & 0 & 47.39 & 8.62 & -68.81 \\
\hline $\mathbf{2 2}$ & 0 & 46.37 & 8.29 & -68.48 \\
\hline $\mathbf{2 3}$ & 0 & 45.35 & 7.96 & -68.15 \\
\hline $\mathbf{2 4}$ & 0 & 44,33 & 7,62 & $-67,82$ \\
\hline & & & & \\
\hline
\end{tabular}

The fraction of stored energy represents the sum of the inlet and outlet fractions in the storage tank during hour $\mathrm{j}$. Because the hot water demand is constant and the availability of solar energy is variable, $\mathrm{Q}_{\text {storage }}$ is negative when there is no solar incidence and varies according to the thermal losses to the environment.

Figure 7 view daily net energy of the solar hot water system does not fully meet the energy demands between May and August. These months present a lower incidence of solar radiation, which entails in less collected useful energy and consequently, in a lower share of stored energy. However, the remaining months present energy surplus. This behavior follows the expected seasonality of solar energy systems.

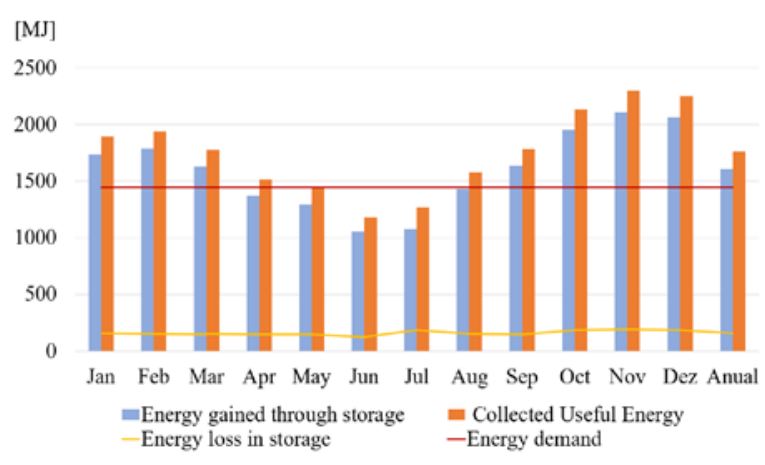

Figure 7. Monthly daily behavior of collected useful energy, energy gain in storage and energy loss relative to demand.

The energy gained in storage is the sum of the collected useful energy plus the (negative) energy lost in storage. In other words, it is the share of solar energy that is effectively converted into thermal energy. This value can also be obtained by adding the energy demand to the energy stored.

The energy lost in storage varies slightly throughout the year; this occurs due to the proportionality between storage temperature and stored energy and the variation in ambient temperature.

\section{Solar Fraction of the SHS}

Table 10 shows the values of the monthly solar fraction of the solar hot water system for a twofold increase in the storage volume, and the losses present in the collector area and in storage. In most months, the solar fraction exceeds $100 \%$; this means that the hot water from the solar system exceeds the demand.

Table 10. Percentage values of the final solar fraction and the total losses of the solar hot water system.

\begin{tabular}{|c|c|c|}
\hline Month & $\boldsymbol{f}$ & Lost Energy \\
\hline Jan & $120 \%$ & $10 \%$ \\
\hline Feb & $124 \%$ & $17 \%$ \\
\hline Mar & $113 \%$ & $10 \%$ \\
\hline May & $95 \%$ & $11 \%$ \\
\hline Abri & $90 \%$ & $11 \%$ \\
\hline Jun & $73 \%$ & $12 \%$ \\
\hline Jul & $75 \%$ & $12 \%$ \\
\hline Aug & $99 \%$ & $11 \%$ \\
\hline Sep & $113 \%$ & $10 \%$ \\
\hline Oct & $135 \%$ & $10 \%$ \\
\hline Nov & $146 \%$ & $10 \%$ \\
\hline
\end{tabular}


Dec

$143 \%$

$10 \%$

The behavior of the solar fraction remains the same; therefore, the increase in its value (even when considering losses) is due to the increase in the storage volume, but it is important to note that doubling the storage volume does not double the solar contribution of the system.

\section{CONCLUSIONS}

A step-by-step guide was presented herein to design a solar hot water system to meet the thermal demands of a textile industry located in Northeast Brazil.

Initially aiming at a minimum contribution of $80 \%$ from the solar hot water system, a $95 \mathrm{~m}^{2}$ collector area was estimated, using 55 solar collectors arranged in 5 parallel sets of 11 collectors connected in series. The storage volume, based on the hot water demand, was calculated as $8 \mathrm{~m}^{3}$, but this value was doubled $\left(16 \mathrm{~m}^{3}\right)$ considering that the solar hot water system can present a variable contribution that is restricted to sunlight hours, whereas the hot water demand is constant throughout the day because the textile industry operates 24 hours a day.

The thermal losses were then quantified to confirm the technical feasibility of the system. Once the operational conditions of the system and the layout of its main components were established, the main thermal losses were calculated. Because the collectors were installed outdoors, the majority of losses occurred in the collectors, due to the wind. The materials employed to build the solar hot water system also influenced the energy losses due to their behavior regarding incident radiation (absorptivity, transmissivity, and reflectivity) and thermal gain of energy (emissivity).

Storage losses were less significant and mostly due to thermal radiation, as the storage tanks can be installed in confined environments (protected from the elements) to reduce convective losses.

An important analysis to be considered is the relationship between the solar fraction and the storage volume of the solar hot water system. The contribution of the system was improved by considering a volume of $16 \mathrm{~m}^{3}$ that took into account thermal losses.

Assuming that a solar water heating system is technically feasible with a minimum solar fraction of $50 \%$, the system proposed herein has been proven to be technically and operationally adequate.

\section{ACKNOWLEDGMENTS}

The authors wish to thank the National Council for Scientific and Technological Development (Brazil), Productivity grant $n^{\circ} 307394 / 2018-2$ and to the Coordination for the Improvement of Higher Education Personnel (CAPES) for the M.Sc. scholarship.

\section{REFERENCES}

Abdel-Dayem, A. M., and Mohamad, M. A., 2001, Potential of Solar Energy Utilization in the Textile Industry-a Case Study, Renewable Energy, Vol. 23, No. 3-4, pp. 685-694.

Abrahao, R., and Carvalho, M., 2017, Environmental Impacts of the Red Ceramics Industry in Northeast Brazil, International Journal of Emerging Research in Management and Technology, Vol. 6, pp. 310-317.

Agbo, S. N., and Okoroigwe, E. C., 2007, Analysis of Thermal Losses in the Flat-Plate Collector of a Thermosyphon Solar Water Heater, Research journal of Physics, Vol. 1, pp. 35-41.

Andrade, J. B. S. O., Dutra, L., Schwinden, N. B. C., and de Andrade, S. F., 2015, Future Scenarios and Trends in Energy Generation in Brazil: supply and Demand and Mitigation Forecasts, Journal of Cleaner Production, Vol. 103, pp.197-210.

Brazilian Association of Cooling, 2008, Air Conditioning, Ventilation and Heating - ABRAVA, Capacitation Manual in solar Heating System Projects.

Brazilian Association of Technical Standards ABNT, 2008, NBR 15569: Direct Circuit Solar Water Heating System, Design and Installation, Rio de Janeiro.

Brazilian Association of Technical Standards ABNT, 2013, NBR 10185: Thermal Storage Tanks for Liquids Destined to Solar Energy Systems Determination of Thermal Performance, Test Method, Rio de Janeiro.

Brazilian Company of Energy Survey - EPE, 2014, Consumption of Energy in Brazil (Sector Analyses), Technical Note DEA 10/14, Rio de Janeiro.

Carvalho, M., Delgado, D. B. de M., and Chacartegui, R., 2016, Life Cycle Analysis as a Decision Criterion for the Implementation of Solar Photovoltaic Panels in as Northeast Brazil Hospital, Energy, Transportation and Global Warming, Springer, pp. 295-310.

Carvalho, M., and Degado, D., 2017, Potential of Photovoltaic Solar Energy to Reduce the Carbon Footprint of the Brazilian Electricity Matrix, LALCA-Revista Latino-Americana em Avaliação do Ciclo de Vida, Vol. 1, No. 1, pp. 64-85.

Çay, A., 2018, Energy Consumption and Energy Saving Potential in Clothing Industry, Energy, Vol. 159, pp. 74-85.

Delgado, D., Carvalho, M., Coelho Junior, L. M., Abrahão, R., and Chacartegui, R., 2018, Photovoltaic Solar Energy in the Economic Optimisation of Energy Supply and Conversion, IET Renewable Power Generation, Vol. 12, No. 11, pp. 1263-1268.

Delgado, D., Carvalho, M., Coelho Junior, L. M., and Chacartegui, R., 2018, Analysis of Biomass- 
Fired Boilers in a Polygeneration System for a Hospital, Frontiers in Management Research, Vol. 2, No. 1.

Duffie, J. A., and Beckman, W. A., 2014, Solar Engineering of Thermal Processes, Wiley.

EES, 2018, Engineering Equation Solver, FChart Software.

Ferreira, A., Kunh, S. S., Fagnani, K. C., Souza, T. A. de, Tonezer, C., Santos, G. R. dos S., and Araújo, C. H. C., 2018, Economic Overview of the use and Production of Photovoltaic Solar Energy in Brazil, Renewable and Sustainable Energy Reviews, Vol. 81, pp. 181-191.

Frey, P., Fischer, S., Druck, H., and Jakob, K., 2015, Monitoring Results of a Solar Process Heat System Installed at a Textile Company in Southern Germany, Energy Procedia, Vol. 70, pp. 615-620.

Globaldata, 2018, Brazil Renewable Energy Policy Handbook, Arena International.

Gnielinski, V., 1976, New Equations for Heat and Mass Transfer in Turbulent Pipe and Channel Flow, International Journal of Chemical Engineering, Vol. 16, No. 2, pp. 359-368.

Grilo, M. M. de S., Fortes, F. C., Souza, R. P. G. de, Silva, J. A. M., and Carvalho, M., 2018, Carbon Footprints for the Supply of Electricity to a Heat Pump: Solar Energy vs. Electric Grid, Journal of Renewable and Sustainable Energy, Vol. 10, No. 2.

Gupta, S., 1989, Scope for Solar Energy Utilization in the Indian Textile Industry, Solar Energy, Vol. 42, No. 4, pp. 311-318.

Jia, T., Huang, J, Li, R., He, P., and Dai, Y., 2018, Status and Prospect of Solar Heat for Industrial Processes in China, Renewable and Sustainable Energy Reviews, Vol. 90, pp. 475-489.

Kylili, A., Fokaides, P. A., Ioannides, A., and Kalogirou, S., 2018, Environmental Assessment of Solar Thermal Systems for the Industrial Sector, Journal of Cleaner Production, Vol. 176, pp. 99-109.

Kurup, P., and Turchi, C., 2016, Potential for Solar Industrial Process Heat in the United States: A Look at California, in: AIP Conference Proceedings, Vol. 1734, No. 1.

Mahadevan, M., and Salai, L., 2015, An Economic and Environmental Analysis of BiomassSolar Hybrid System for The Textile Industry in India, Turkish Journal of Electrical Engineering \& Computer Sciences, Vol. 23, No. 6, pp. 1735-1747.

Mathworks, 2018, Matlab Software, Version R2018b.

Muneer, T., Maubleu, S., and Asif, M., 2006, Prospects of Solar Water Heating for Textile Industry in Pakistan, Renewable and Sustainable Energy Reviews, Vol. 10, No. 1, pp. 1-23.

Munner, T., Asif, M., Cizmecioglu, Z., Ozturk, H. K., 2008, Prospects for Solar Water Heating within Turkish Textile Industry, Renewable and Sustainable Energy Reviews, Vol. 12, No. 3, pp. 807823.

Suresh, N. S., and Rao, B. S., 2017, Solar
Energy for Process Heating: a Case Study of Select Indian Industries, Journal of Cleaner Production, Vol. 151, pp. 439-451.

Pereira, M. G., Camacho, C. F., Freitas, M. A., and Silva N. F. da, 2012, The Renewable Energy Market in Brazil: Current Status and Potential, Renewable and Sustainable Energy Reviews, Vol. 1, No. 6, pp. 786-802.

RadiaSol 2, 2010, Solar Radiation Software, Solar Energy Laboratory, UFRGS.

Sharma, K. A., Sharma, C., Mullick, S. C., and Kandpal, T. C., 2017a, Solar Industrial Process Heating: A Review, Renewable and Sustainable Energy Reviews, Vol. 78, pp. 124-137.

Sharma, K. A., Sharma, C., Mullick, S. C., and Kandpal, T. C., 2017b, GHG Mitigation Potential of Solar Industrial Process Heating in Producing Cotton Based Textiles in India, Journal of Cleaner Production, Vol. 145, pp. 74-84.

Sharma, K. A., Sharma, C., Mullick, S. C., and Kandpal, T. C., 2018, Incentives for Promotion of Solar Industrial Process Heating in India: a Case of Cotton-Based Textile Industry, Clean Technologies and Environmental Policy, Vol. 20, No. 4, pp. 813823.

Silva, R. C., Marchi Neto, I., and Seifert, S. S., 2016, Electricity Supply Security and the Future Role of Renewable Energy Sources in Brazil, Renewable and Sustainable Energy Reviews, Vol. 59, pp.328341.

Struckmann, F., 2008, Analysis of a Flat-Plate Solar Collector, Heat and Mass Transport, Project Report.

Youssef, W. B., Maatallah, T., Menezo, C., and Nasrallah, S. B., 2018, Assessment Viability of a Concentrating Photovoltaic/Thermal-Energy Cogeneration System (CPV/T) with Storage for a Textile Industry Application, Solar Energy, Vol. 159, pp. 841-851. 